DANDELION

postgraduate arts journal \& research network

VOLUME I NUMBER I SPRING 2010: GENRE
Max Sexton worked for fifteen years in television in the UK and abroad before returning to complete an MA in Film and Visual Media at Birkbeck, University of London. He is presently doing a PhD at Birkbeck with AHRC support. Max's research interests include the use of film and video technology in cinema and TV, industrial cultures and technology, and style, narrative and genre in the age of cinema, TV, and networked media.

Email: maxlondonuk2001@yahoo.co.uk

\title{
Article
}

\section{Celluloid Television:}

\author{
The Action Adventure Genre of the 1960s
}

Max Sexton

INHERENTLY LIKE FILM, yet antithetical to it. Contradictory theories abound regarding what television can and cannot do, about what it does best. In the early years British television was governed by Reithian values of 'public service' and 'high culture'. But the emergence of a transatlantic market in television programmes in the 1950s - together with the use of celluloid - opened up the televisual in Britain. This process will be examined by focusing on two examples of the action adventure genre, The Avengers and The Prisoner. The article will explore the material industrial processes involved in the creation of a new set of conventions in the genre.

The success of Desilu Productions in America demonstrated that as early as 1951 sponsors and audiences had a preference for filmed entertainment on television. ${ }^{1}$ By using conventional Hollywood filming and production techniques, the content of such western shows as Cheyenne and Bonanza, cop shows such as Dragnet and The Untouchables, and Desilu's most memorable show, Star Trek, was immediately established as 'high quality'. The rhetoric of all filmed television drama appeared to be a cinematic rhetoric - framing, distance, lighting, focus, filter, and assembling images together into a coherent 
sequence. This rhetoric was also easily adaptable to different forms of comedy or drama, indoor sets, outdoor sets, or special effects. Once the sponsors and broadcasters realised that entertainment shot on film was attracting large audiences, increasingly the schedules were filled by shows that had been shot on $35 \mathrm{~mm}$ film. The technology of film was no longer reserved for the cinema, but watched by an audience at home, fulfilling a hope by Thomas Edison nearly a century old:

\begin{abstract}
I hope to be able by the invention [of moving pictures] to throw upon a canvas a perfect picture of anybody, and reproduce his words...A man will be able to sit in his library at home, and, having electrical connection with the theatre, see reproduced on his wall or a piece of canvas the actors, and hear anything they say. ${ }^{2}$
\end{abstract}

Edison envisioned the future integration of existing media technologies, merging the capacity to record sounds and images with the long distance transmission of signals provided by the telegraph and the telephone, so as to bring the theatre and the spectacle of the whole world into the home. Peter Kramer concludes that, 'the cinema arose then out of what I would suggest could be called Edison's 'televisual imagination'.

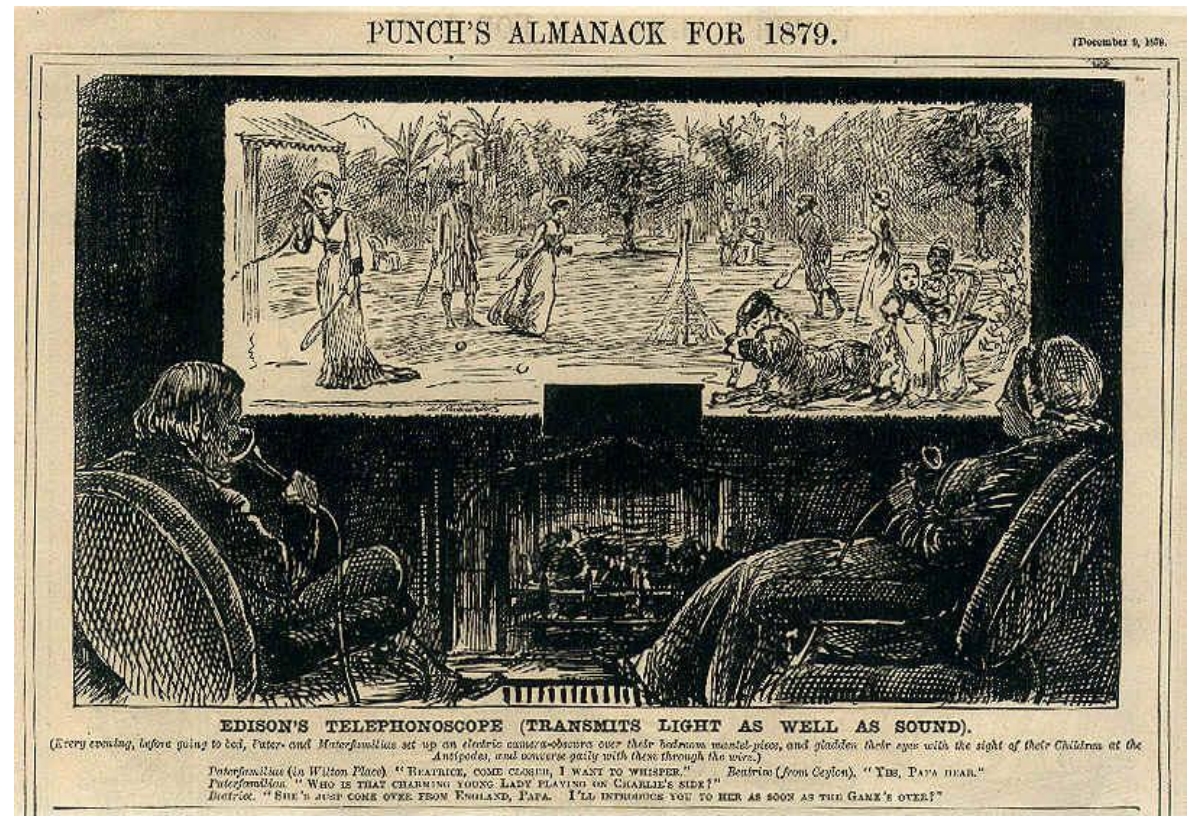

'Edison's Telephonoscope (Transmit Light as well as Sound)', George du Maurier, Punch, 8 December $1878^{4}$

It was only in 1895 that the first public exhibition of moving pictures, instead of bringing the world into the home, brought the world into the theatre. The success of the theatrical projection of films to paying audiences after 1895 meant that film technology became identified with the big screen and theatrical spaces, culminating in the movie palaces of the 1930s, when film achieved its 
most public character as a medium. Roy Armes has suggested that it is the huge economic and cultural impact of the big screen theatrical presentation that constitutes film's uniqueness within the proliferating technologies of sound and image reproduction during the twentieth century:

It was the only one of the new media to be developed as a public entertainment and to adopt a theatrical, rather than a domestic mode. All subsequent developments in the reproduction of sounds and images have been directly home-oriented. ${ }^{5}$

When Radio City Music Hall in New York was opened with a seating capacity of 6200 by RKO in December 1932, it became the world's largest motion picture house and marked the acme of film's development as a big screen theatrical presentation.

Yet even as the greatest theatrical picture palaces were being built in the 1930s, a re-integration of domestic media technologies and theatrical film entertainment was taking place that presaged future developments in the period 1950-65. In America, unlike Britain, live drama was never theorised as television's essential characteristic by the network chiefs, the advertisers or the mass audience. As early as 1944 an industry observer was quoted as saying:

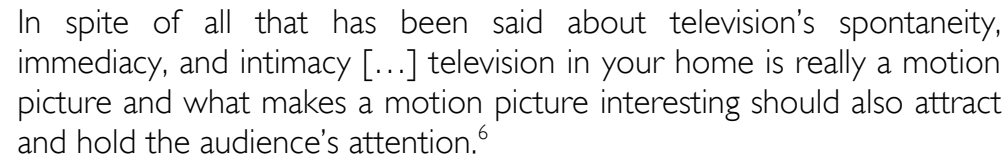

By the mid-1950s, corporate interests in Hollywood had their eyes on the potential of filmed drama on the small screen. By now, the contrast between the relative poverty of the studio-based 'live' image and the potential of film was readily apparent. Live plays were often characterised by disaster striking in many forms, from the leading man falling sick to the side of the camera falling off and hitting the floor during a whispered love scene. ${ }^{7}$ In the U.S., shows were sponsored by advertisers and each live play typically had three acts interrupted by the sponsor's 'message'. The advertisement was often in the form of a slickly-edited piece of film and the quality of the image and the pace of the editing reflected badly on the studio-bound play that contained it. The new television industry was slowly being positioned in relation to its significant economic 'others' - the advertising industry, and later, the motion-picture industry. The dominant interests in television's commercial development had succeeded in producing a synthesis of old radio's programming and merchandising goals with the persuasive tools of Hollywood's film-making, ensuring that the new television medium would not ignore sales-making opportunities by ignoring the value of 'entertainment'. The major Hollywood studios, encouraged by the advertising industry, turned over much of their spare studio capacity to making the filmed action adventure series to meet the networks' seemingly insatiable demand.

Writing about 1950s television drama in the USA, Richard Patterson notes: 
There was a certain inevitability about the changes. Series were easier to schedule and allowed the networks to amortise fixed costs over a longer period [...] The filmed series [...] had a number of advantages [...] regular characters and situations with a returning audience, schedule anchorage, efficient production, easy sale of advertising [...] [They] dominated ratings in the USA from the early 1960s, and were sold across the world to equal success with international audiences. ${ }^{8}$

A report by Philip Mackie on the widespread use of film on American television appeared in Sight and Sound in 1954. Mackie made a useful distinction between two styles of TV film. One school of producers tried to reproduce on film the virtues and limitations of the 'live' show, perhaps best exemplified in Groucho Marx's comedy. The other school 'made their film look like films, with chases and running fights shot against location exteriors. ${ }^{9}$ Such films would continue to proliferate and the mid-1950s saw a big expansion of filmed western series, the entry of Alfred Hitchcock into telefilm production, and in Britain, the opening up of ITV, whose sharpest entrepreneurs quickly recognised the economic possibilities of using film. ABC's Robin Hood was an early British example of the quickly-filmed action series that copied the American technique of industrial television production using film: repeatable and exportable, it became a profitable commodity.

The use of celluloid in television opened out the televisual experience and helped to rescue television drama from its theatrical affiliations (where it would have continued to be a relay device for a pre-existing, live performance). The popularity of the western in America, and even more so the action adventure genre in Britain - in series such as ITC's Danger Man, The Prisoner, and $\mathrm{ABC} /$ Thames Television's The Avengers - suggests that film medium gave to early television audiences a sense of the 'epic' and a feeling of the width of cinema that was in sharp contrast to the confined world of the 'live' studio drama. The sense of scale was achieved because it was inscribed into the iconography of the genre as it developed. Patrick McGoohan's protagonist, John Drake, in Danger Man was frequently called upon to intervene in the internal politics of islands in the Caribbean, and in the episode Colonel Rodriguez (1960), he facilitates the release of an American from the island of Montique. The settings and place names could carry resonances of the genre's epic space. However, what was evoked was an imaginative rather than an actual geography. The imaginative space was evoked through every aspect of costume, set design and mise-en-scene, no matter the budget restrictions.

\section{Celluloid Television: Technology and Culture}

To understand how the debate on celluloid aesthetics on television in Britain took on a particular character, it is necessary to consider the relationship between the technology of film and the technicians using it. Although television is an electronic medium, it has often relied heavily on the film for a large proportion of its programme origination. Throughout the 1970s and 80s, with the ascendancy of video, a variety of questions around an implicit 
hierarchy of mediums appeared. Film began to look like a messy, outdated mode. It is reasonable to ask why it had not disappeared altogether. However, film appears to have fulfilled the needs of the programme makers, and it continued to be used, not only for technical and economic reasons, but also for aesthetic and cultural ones. Frank Watts, cameraman on television's Hammer House of Horrors, has stated that atmospheric shadows, silhouettes, movement of both camera and cast, and lighting levels, are largely responsible for the success of a good horror movie. Shooting on video, on the other hand, appeared as a real limit to creative potential.

'I cannot think of a more appropriate stock than $35 \mathrm{~mm}$ colour film to give outstanding shadow details making the lighting cameraman's life far more straightforward. Film really helps; you couldn't do justice to this series with electronic production. There is more control to start with; with a single camera you can get places that the video camera can never get at - well, not at the price anyway. Shooting with one camera means lighting for only one camera; in atmospheric work that is usually the only way you can do it convincingly. For me, film is more versatile. That may sound strange when you consider what can be done with electronic originated pictures. The answer, however, is on the screen in your sitting room...'10

Much has been said and written about the look of images on film. Attempts have been made not only to define it, but also to reproduce it by using videotape. It is doubtful that there is any one factor that produces the 'film look'; rather, it is the product of techniques and technology that have evolved over a period of more than one hundred years.

In the 1970s Stuart Hall asked whether there was a formal aesthetic which could embrace the heterogeneous contents and occasions of television within a single coherent language. 'Despite its massive heterogeneity, there does seem to us a single, coherent language of television to which all its different practices can be referred. The language is, for all practical purposes, indistinguishable from the cinema." ${ }^{11}$ Although television continually cannibalises and hybridises the content and presentational forms of other media and events or occasions, the universal set of practices by which this heterogeneous raw material was transformed into television was a set of conventions that, according to Hall, derived from the cinema.

For Hall, there was the danger of regarding television as unmediated, because it appeared that what made television distinctive was the relatively low level transformation of the bulk of its contents, and the very high proportion of television's raw material that was itself the content of another medium, e.g. live theatre or a cinema film. He blamed this on the lack of a 'social aesthetic' on television because of the institution's often innate conservatism. He believed that television did not lack an intrinsic form, but that its powers to transform its content were subjected to a sort of collective repression by the staff involved in the creation of television programmes. For Hall, television's use of a set of conventions taken from the cinema was on one level an acknowledgement that they shared many similarities, but also a condemnation of what he believed was television's formal underdevelopment. 
However, it can be argued that television does not represent a different medium, but should be understood rather as a continuum with cinema. As such, it can be best described as a single medium that has undergone a constant process of renewal since the invention of moving pictures. The modes of transmission may have changed from the theatrical to the domestic, but the cinema viewer has become a television viewer as programmes have been reduced in terms of size and scope but expanded in terms of information and activity. Instead of assuming cinema's pre-eminence, as the bearer of a greater cultural capital, it can be argued that false distinctions are often made between cinema and television, and that there has often been a convergence in their development. The latter has involved a two-way process in which the existing modes of representation were updated in both cinema and television to secure further relevance within moving images.

The creation of a specifically televisual rhetoric using celluloid for a domestic rather than a theatrical cinema can be assessed by examining how far the issue of 'technical quality' - the degree of control over the visual style took second place to the scripting of action and narration in a show such as The Avengers. In 1967, The Avengers was at the point when it ceased to be shot on video and in black and white and was updated by the 'new medium' of colour and $35 \mathrm{~mm}$ film. The decision to shoot on film led to a more frequent use of exterior shots, and production teams coming to the series sought to create a 'film look' that was more artistically pleasing in the quality entertainment/drama field.

\section{Occupational Ideologies at Work}

The 'hard work' of making a genre series shot on film needs to be understood in relation to the industrial and economic context of the series. An examination of the conditions of production of the series (rather than, say, an analysis of the role of professional ideologies in the organisation of a television production) will help to clarify the situation here. Firstly, it will tell us about the existing ideologies with which the production team were concerned, and secondly, it can also expose the contradictions between an ideological project conceived by the programme makers and the final programme as it is read and consumed by audiences.

Pierre Macherey has spoken of the difference between conditions of production and determining factors. A text is not simply determined but can take into account its physical and mechanical conditions of production, together with the technological and social relations of production. The conditions of production constitute a principle of rationality, which makes works of fiction accessible to their audience rather than existing as a cause in the empirical sense. As Macherey puts it,

[t]o know the conditions of a work is not to reduce the process of its production to merely the growth of a seed which contains all its future possibilities from the very beginning [...] To know the conditions of a 
work is to show how it is composed from a real diversity of elements which give it substance. ${ }^{12}$

This operates against the notion of literary works conceived of as 'created' and 'finished' products and towards the analysis of literary texts as they are reinscribed in a variety of different institutional and ideological contexts. Studying a particular text does not require elevating it and isolating it from its history of productive consumption, but looking at everything about it, 'everything which has collected on it, become attached to it - like shells on a rock by the seashore forming a whole incrustation. ${ }^{13}$ In other words, the production of a fictional work is a process, and the labour involved in that process can transform the ideology held by its producers and may be symbolised within the finished text. The ideological is given a visible form within a programme and the conditions of production reformulate its particular articulation.

This reformulation is partly illustrated in an account by Alan Hume, the lighting cameraman for The Avengers in 1967. Hume has spoken of the diligence he took planning the lighting and which can be traced to the 'professional' qualities of a crew used to high technical standards in the film industry. The sense of making a 'mini-film' was more readily felt because they were using familiar equipment such as a BNC Mitchell camera, the standard blimped camera that was used by Hollywood prior to its replacement by the Panavision technology of the late 60s and 1970s. At times, due to the economic pressure of deadlines and budget, the subject matter of the script for The Avengers was often limited by the set design and lighting. However, shooting on film with an experienced crew was very different from shooting in the studio. For example, television engineers in the studio would strongly disapprove of brilliant whites and of solid non-reflective blacks, especially if they were in large quantities, because they were of the opinion that the electronic signal of the T.V. system would not cope with highlights and lowlights. These limitations set by the studio engineers were absent when filming on location. During the filming of one episode of The Avengers the film crew were faced with having to film a set that represented a coalmine. They were faced with black walls and the actors walking about in dark costumes, moreover, there was virtually no light source. One option would have been to light the set, as would have happened if shooting had been in the studio, but this would have made it appear unrealistic, in the same way that an actor using a torch in a supposedly dark room which is obviously well lit up is unrealistic. Instead, Hume conferred with the art director, who, he records, would go to any possible lengths to be helpful. The solution was to liven up the scene by adding mist. Mist in a coalmine was unrealistic, but it looked remarkably effective, and as Hume says, 'really did come over. ${ }^{\text {, }}$

A fictional work is a process, and the collaborative nature of film-making can allow a solution to a technical problem that can lead unexpectedly to the creation of a scene content that is artistically more interesting than that envisaged by the script. Of course, the degree of difference could amount to a complete break from the script, but Hume makes it clear that a crew's overriding purpose was to maintain the integrity of the script, and to serve it 
rather than alter or replace it. Nevertheless, the diligence of the 'professional' crew should be seen as opening out the televisual experience as much as the use of film as a technology. One reason for setting up a film company in the 1960s to produce for television was the degree of flexibility in working practices that it made possible. For the producers of The Avengers the experience, first at $\mathrm{ABC}$ and later Thames Television, demonstrated that freelance working could produce a change in the social relations of production, which can affect the final textual meanings that are being offered in a programme. Instead of the often alienated workforce of permanently staffed technicians in the television studios who were unlikely to work consistently on a long-running drama series, Thames' employees producing The Avengers had the chance of a closer involvement with the programme as a whole and crew members were rarely unwilling to work overtime because they were more actively involved in a production.

By the end of the third season in 1964, The Avengers was on the verge of a major technological change. Until that point, the series had been recorded on videotape, which was difficult to edit, and so the performance had often to be done in a single take with only a handful of exterior scenes shot on film. These technical limitations were overcome by the use of interior sets, close shots and a visual style that used low-key lighting and expressionist angles to create an unreal world that was marked off as different from the realism of a neardocumentary series like Z Cars. For the fourth series in 1965, however, The Avengers moved onto film, which was more expensive, but allowed a greater use of location filming, exterior sequences and a more expressive use of visual style. The reason for the change was in large measure due to the desire to sell the series in America where filmed entertainment had been established much more firmly than in Britain.

The move to film necessitated changes in the production base of the series and its personnel. If there was a moment when The Avengers can be said to have changed decisively, this was it. The production base of The Avengers moved to British National Studios at Elstree. Julian Wintle, a former film editor turned producer who had co-founded Independent Artists in 1958 and whose credits included Tiger Bay (1959) and This Sporting Life (1963), was brought in as supervising producer. Yet the credos of actual personalities such as Wintle and Thomas were not as important as a set of complex 'signature' codes that suggests both authorial and cultural importance. From the critical tradition of authorship came the still-dominant popular view that individual, artistic directives were at the heart of the creative enterprise in film. However, the personalities of each studio in the classical era of Hollywood were not a priori to the film, but added in because of the controlling oversight of the studio bosses. ${ }^{15}$ This worked because specific production modes distinguished each studio. Similarly, ITC and ABC/Thames utilised a 'house' mode of production; they also shared 'house styles' with other filmed entertainment on the lot.

Television programmes are industrial products produced for a mass audience, and therefore the study of popular TV demands that the critic recognises that programmes do not stand alone, but are produced and consumed in runs and sets, groupings that may be understood in terms of generic qualities, or the casting of stars, or shared iconographic elements. 
Rather than the discrete programmes, it is the continuities across groups of films that the audience recognises, and that become the principal focus of critical attention. The primary object of study is not the single programme, but the series that was shaped by several factors; occupational ideologies that influenced the use of film on television; the cultural understanding of television aesthetics and technology. Steve Neale has argued that 'genres cannot be systematically characterised and differentiated from one another' on the basis of abstracted formal properties - a set of codes and conventions - as if such properties 'constituted specific generic essences'. ${ }^{16}$ Rather, he argues, genres can more usefully be viewed as sets of expectations through which the possibilities of understanding a text are organised. Such expectations are neither lodged within nor produced by the properties of individual texts or even groups of texts viewed in isolation. The determination as to which genre rules will be operative in organising the possibilities of reading is thus linked to a production culture, rather than a fixed set of conventions within a text.

\section{Transatlantic Pop Aesthetics}

As television production moved to involve an international market, there was a growing Americanization of the action adventure genre. This relied on the industrialization of the aesthetics of film that had happened in America. In The Avengers the comic strategy of the series also operated to recruit new audiences. The parodying of some aspects of post-imperial ideologies such as consumerism and fashion, combined with the buttressing of others, was not only endorsed by British audiences, but also allowed The Avengers to engage with international audiences. This, in turn, fed into American views of the British class system as an outdated anachronism, and served as an amusing ideological eccentricity when used in the service of the West (i.e. the United States). In this way The Avengers can be understood as linking together American and British audiences.

The importation of the American filmed television series whetted British audiences' appetites for this style of entertainment, and the imposition of quotas on foreign material that could be shown on British television stimulated the production of the filmed series in the UK. It was Lew Grade who first began to finance the production of the TV film series under the BFPA (British Film Producers Association) agreements, after convincing the unions that this would not affect the production of television programmes within ATV (Associated Television), but would allow him to break into the American market, and provide an additional source of employment. After his TV series Danger Man was shown successfully in the US, but not networked, Grade sold his first TV series to America in 1965. The Saint, which had cost ATV £50,000 a show to make, was bought by NBC, and was the first British-made TV series to be shown on the American network. It ran in the US for 117 episodes. Meanwhile, in 1965, Howard Thomas, at ABC, switched The Avengers from tape to film and scored a notable success, including an American network sale.

The main aesthetic that appeared in the new filmed version of The Avengers was the pop ethic. By then the action adventure genre had become the dominant fictional form of the 1960s pop ethic, because the genre had become 
additionally coded with discourses related to tourism, conspicuous consumption and sexual pleasure. In particular, the action adventure successfully appropriated the new pop aesthetic of the designer gadget. The use of the gadget, omnipresent in The Avengers, Danger Man and The Prisoner marks a radical break with previous conceptions of modern technology and instead, the micro-electronics of the gadget foreshadowed a future in which advanced technologies were to be consumer products on a mass market. Pop art became the freeing of the art of technology from its military-industrial connotations. The gadget was deployed without brute force, but coolly in the hands of a professional individual.

The gadget is designed for a precise, functional use and plays an important role in the accomplishment of the mission of the protagonist. The use of miniaturised, concealed cameras, listening devices, tape recorders and closedcircuit video enabled Drake, the main character in Danger Man, to gather information that would otherwise be beyond the resources of a lone agent. The deployment of gadgets allowed the secret agent to overcome the passivity of his fellow lone operator, the private eye. In Danger Man, the information giving role is transferred to the gadget, freeing encounters with others for ideological rather than narrative ends, and enabling the planting and monitoring of electronic bugs to become an 'active' process which slows down the narrative to the strains of cool bass lines and jagged harpsichord notes. The series testifies to an art/technology combination.

In the episode Parallel Lines Sometimes Meet, there is a condensation of the pop alliance between the worlds of fashion and advanced technology. Drake is always impeccably dressed, his clothes barely ruffled even after fights and chases: most episodes could also be read, at least in part, as a prolonged demonstration by a male model. At the same time, he is also a skilled manipulator of gadgets and instruments. As well as his technical skills, his missions also demand a vast general cultural understanding in order to appear convincing in his various impersonations. Drake thus assembles within his character, the roles of technician, artist and intellectual that form different aspects of the new middle class. The art/technology mix is also a blend of the old and the new. Drake is a carefully crafted design of the new, modern person, running a line of continuity between yesteryear's spy of morality and patriotism, and the ironic view of the old that is receptive to the new. He is emblematic of the modern individual, the spy of technical and social skills that can avoid having his cover blown by not making mistakes.

Pop irony and moral seriousness are constantly in tension, the signs of consumption and technology straining against older values. The positioning shots of London and other capitals are a sign of pop's cosmopolitanism in which the foreign is able to signify the modern and the progressive. Continental values are similarly marked as signs of stylish consumption in Danger Man. Drake's presence in foreign cities, rather than reinforcing his Britishness, is a chance for him to show off his cosmopolitanism and his ease in another culture. By the end of the 1960s, the action adventure genre had fissured into two distinct forms. On the one hand, filmed entertainment of playboys who carried out vague missions in tourist playgrounds against mysterious international organisations; on the other, the ultra-realist genre and the return to a 'live' 
studio-bound mode in Callan (1967-74), in which unglamorous, shadowy characters went about their way in a morally ambiguous world.

The Avengers and The Prisoner were both nominally espionage-related dramas, and both deconstruct the spy genre, though in different ways and with different intentions. They incorporated sci-fi elements, helped to create the hybrid genre, spy-fi, to feature strange robotic menaces, and strayed from the standards of their genre as they became politically charged and consistently satirical.

The achievement of The Avengers was to contain within itself the pendulum swing from realist aesthetics based on a 'live' mode of television to surrealism based on notions of entertainment associated with film. This demonstrated the flexibility of the television series as a form and the centrality of its style to the way it was marketed. So, for example, a series like The Avengers could reach a key demographic for advertisers - 18 to 35 year olds by offering entertainment that was sensitive to all these different demands, and which exploited television as a medium and film as a technology within television.

During the 1960s the primary point of cultural reference for a television programme remained the first moment of transmission. Unlike cinema, television programming was heavily tied to specific times that were used to construct a sense of intimacy with a domestic audience. Consequently, regardless of the genre or the fact that it was 'popular' or 'serious', programmes usually made reference to a common present moment and involved programme makers and audiences with shared assumptions. For example, the representation of fashion in The Avengers, which became more evident in series four, was manifestly of the moment. The Emma Peel outfit was the first publicly available clothing collection designed for TV and the retail sales it inspired followed a show at the Courtaulds Fashion Theatre in August 1965. Diana Rigg would soon be associated with her iconic target beret, and the signs and images that denoted conspicuous consumption were used to place the characters of Emma Peel and Steed and enable the audience to relate to them as being emblematic of pop style, youth and glamour. It is worth stressing that this everydayness of TV, where references are constantly being made to a common present moment, can present additional problems of textual and generic interpretation that may not exist to the same degree in cinema.

One of the pop elements deployed by The Avengers was a series of intertextual references and quotations from other media, often referred to as 'bricolage'. The show was more rigorously 'pop' than Danger Man, which presented 'pop' style within a framework of political dilemmas. Foregrounding the pop obsession with designed surfaces, later episodes of The Avengers eliminated all trace of psychologically realistic characters from its content. These features were an integral part of another style of series that began in America at the beginning of the 1960s, exemplified by The Man From Uncle, which eschewed the 'realistic' illustration of social and psychological truths in favour of glamour and consumption. The focus on surface appeared thematically and we see 'speed' and 'modernity' revealed in a number of forms. Certain clothes become 'as fast and slick as a jet plane'. ${ }^{17}$ The reduction or flattening out of the idea into real objects was integral to pop style, for instance, 
in the episode, The Interrogators, an undercover informant is shot dead while kicking a football (bucket).

The pop series required a new gaze from viewers, one ready to derive visual pleasure from highly detailed photographic images as part of a narrative based on the consumption of fashionable images. On BBC radio in 1963, Harry Craig confessed:

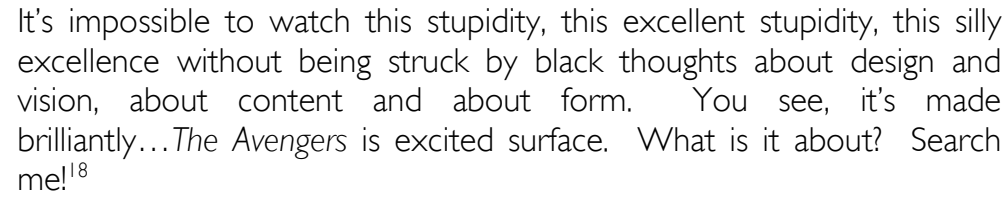

Psychological identification with characters was dismissed as unsophisticated. The pop gaze established a new regime for the television series, no longer based on the outside world but on the higher reality of design. The development of modern consumerism meant learning to pay attention to detail. This type of fetishism invested objects with systems of signification, and the inability to read surfaces correctly amounted to a lack of 'sophistication' on the part of the audience.

With The Avengers, the enjoyment for some people is tied to the fact that less sophisticated viewers will view it as alien. The quality of the text worked as a social marker rather than providing an objective basis. The pure gaze of the cultivated, sophisticated arbiters of culture defined itself by its opposition to the simplicities of the popular. The analysis of television drama as both a quality and popular form opened up a means of linking the aesthetics of television drama to the dialectics of sense-making and taste-making. In Britain, Stuart Hall argued that the general rule is that the more serious or 'high culture' a dramatic production is, the less it will be conceived for television and the more television will borrow forms from other media. Television will either transmit a 'serious' play as a piece of theatre or else transmit a popular piece of drama as a piece of cinema instead of finding a form more appropriate to television. However, The Avengers challenges this simple dichotomy. The distinction between a popular and the high aesthetic was bound up with the struggle between a populist, and classless American television that came to be associated with filmed entertainment, and a much more class-based British form of television with aspirations to art and seriousness more associated with 'liveness' and the single play on television. It is precisely because The Avengers exemplifies technological changes in the television industry, moving from 'live' performance to film and from black and white to colour in 1965-67, that it also exemplifies stylistic changes that occurred in the action adventure genre in television from a low-key, realist mode of representation to a more colourful, fantastic style strongly influenced by pop art and fashions of the time. It is as a product of the 'high sixties' that The Avengers is most celebrated. As such, it made visible the ideologies of consumerism, in the process 'opening out' the televisual experience on celluloid.

With film recording, television programmes began to acquire the definitiveness and fixity that is normally associated with a separate text, and repeats of viewers' favourite programmes came to occupy a significant part of 
the schedule. With repetition, recorded programmes also acquired the status of commodities or 'tradeable goods'. ${ }^{19}$ Filmed drama, and eventually, the new technology of magnetic recording after 1958 meant an enormous expansion of television's programme base. Stockpiled recordings could be used not only for delayed or repeated transmission but as goods that could be traded among broadcasters.

With its foregrounding of signs of expensive consumerism and conspicuous consumption - the cars, clothes and champagne drinking - The Avengers was well placed to become a highly commodified text, taking full advantage of the new market in programmes. Not only could the series be traded among broadcasters; it was also the first television series to employ an 'exploitation manager' to sell product placement to companies anxious to have their commodities showcased. Props such as Emma Peel's sporty Lotus Elan were signifiers of modernity, just as Steed's vintage green Bentley reinforced the character's links with other fictional agents and advertising totems such as James Bond. The prominence accorded to designer clothes and other consumer items was an integral element of the series' production strategy. The Avengers was 'packaged' to present an image of England as a place of high-living and sophistication that would appeal to affluent overseas audiences who might wish to invest in British consumer culture.

In the mid-1960s, at the time of programmes such as The Avengers and The Prisoner, popular culture was enjoying unprecedented prestige and influence. 'The characters often had elaborate biographies, couched in a weirdly seriocomic style, the fruit of earnest script conferences.' records one contemporary journalist. ${ }^{20}$ Meanwhile, on television, programmes like Armchair Theatre, and the Wednesday Play, and topical magazine programmes such as Panorama and Huw Wheldon's Monitor continued to be shaped by social realism - and the still prevalent Reithian patrician principle of public service broadcasting. The popular genre of the action adventure series with its various sub-categories was all too often dismissed as imitative of American television, and lacking the social realist import or the literary pedigree seen as the hallmark of the 'best' (meaning the most critically respectable), British television. When a popular genre did receive some critical acclaim, it was not done on the basis of its own generic characteristics, but through its perceived relation to the realist tradition (as in the case of Doctor Who).

The cultural status of the action adventure genre is controlled by attitudes to high and popular culture, and what constitutes art and quality. The Avengers, like many popular shows, was not taken seriously by most television critics of the 1960s, and was believed to be ephemeral because it privileged style over content and refused to engage with the 'real' world. However, Kingsley Amis suggested a different way of appreciating The Avengers that was not determined by conventional notions of narrative logic. For Amis, the absurd narrative was a sign of a sophisticated production strategy. ${ }^{21}$ In fact, the desire to avoid social reality was a deliberate production strategy of the series from 1965 onwards. Bruce Merry argues that while 'espionage fiction trips over itself to play the game of culture', it does so only to debunk the game, to deflate the signs of culture and knowledge which the text displays precisely by foregrounding them as a 'paraded literariness. ${ }^{22}$ According to this view, a show such as The Avengers 
could be read as a subtle anti-literalising device, a parading of signs of value which reveals them as valueless, and furthermore calls into question the making of signs.

\section{'High Culture' Entertainment: The Prisoner}

The Prisoner was produced by Patrick McGoohan's production company Everyman Film Ltd for ITC. At this time the single-authored and homogenised text represented by the mode of realism and 'liveness' on British television and its Reithian tradition, was considered the aesthetic peak, because they connoted seriousness and 'quality'. The contributions of other writers, directors and producers to the series were overlooked in the promotion of The Prisoner as a 'single-authored' series. In a move typical of the publicity promoting the series at the time of its transmission, the TV Times attributed the creativity of the series to the authorship of McGoohan:

McGoohan believes that he is breaking into completely new television territory - in presentation and stories alike. The idea is his own. He is also the executive producer. He has taken over the direction of many of the sequences (but without giving himself a screen credit for this). He has buried himself in the cutting-room during the editing of the episodes. And he has worked on every script, irrespective of who may have written it. ${ }^{23}$

The Prisoner was broadcast in 1967-68 and ran for only seventeen episodes. It centres on a secret agent who resigns from his job and is then abducted and held in a mysterious 'village' where the authorities try and make him reveal the reason for his resignation.

Contemporaries did not know what to make of The Prisoner. When it began it was welcomed as a bold and innovative experiment that offered a different entertainment pattern from the formulaic norms of popular television. However, the appeal to aesthetic value was linked to a strong emphasis on the generic elements of The Prisoner as an action adventure series.

It adopted in many ways the generic conventions of the 1960s television spy series found in earlier series such as Danger Man and The Avengers. These series pitted their spy protagonists against villainous individuals and organisations, combining elements of the detective and thriller genres in the use of intriguing narratives and action-packed denouements. In the first episode, The Prisoner promised to fulfil all of these generic expectations. The opening credits showed McGoohan driving into London, entering a building and resigning. The central London setting, the costuming of McGoohan as Number Six, and the man he resigns to in a dark suit suggested a government agency. A shot of a vast underground filing system confirms this is a powerful and large, secret organisation. The exotic location to which Number Six is kidnapped to is also in keeping with the conventional use of exotic locations in Danger Man. However, although The Prisoner sets up these generic expectations, they are consistently undercut and unfulfilled. The identity of the 
organisation from which Number Six resigned is never revealed, and references to the spy genre are only implied rather than asserted. The Village that the prisoner is taken to may be run by a villainous organisation or by a government. Number Six may be a spy concealing information. The Village may be set in a foreign locale, but this is never confirmed.

The combination of the fantastic and the familiarity of the genre series in The Prisoner was used to create popular entertainment, but also a show that could be regarded as 'serious'. It negotiated this contradictory position partly by relying on being filmed. This associated it with conventional Hollywood filming and production techniques, so that it signified a slickly scripted and produced content. At the same time, The Prisoner series is a television epic that is colourful, defiant and challenging. The editing of the scenes in many episodes is unusually fast for a typical series. One of the most important scenes is when Number Six meets Number One in Fall Out and lasts only for a few seconds. McGoohan wanted his audience to think about what they were watching and to fight off the temptation to arrive at simple or superficial conclusions. Instead, there is a positive delight in meeting the challenge of The Prisoner head-on. Many critics have subsequently recognised the power of the television serial - as exemplified in The Prisoner - to give voice to an increasing number of perspectives and points of view. ${ }^{24}$

In the 1960s, television was still a relatively new form of mass entertainment. Although it had become a force in its own right, the medium had not yet become self-reflexive. Few programmes addressed the nature and effects of television itself. The Prisoner was the first television series to be about television. It explored the technical and expressive possibilities of the medium, and probed the viewer's status as watcher. The portrayal of technology was anything but attractive and consumer-oriented - a condemnation of technology-oriented Western materialism. The essential purpose of The Prisoner was to raise questions about the relationship between self and society in the technocracy of the global village.

\section{The Problematic Uses of Action adventure}

In Danger Man, and particularly The Prisoner, McGoohan's professional identification with the television industry was evident in his very 'visual signature' and use of the latest television technology. The earlier classic realism of Danger Man had been overwhelmed by the over-proliferation of authorship. However, the institutional rather than the personal or biographical logic of authorship in production became the key factors here. Television needs to be viewed as an industrial - rather than artistic - practice and a television production could demonstrate authorship to be unavoidably collective, and contested.

The use of the pop aesthetic in television was in many ways the consequence of shifts within the structure and organisation of the industry from the production of live drama associated with 'high culture' to a more Americanised use of the action adventure genre that relied on the aesthetics of film. In The Avengers the comic strategy of the series also operated to recruit 
new (mass) audiences. Within this industrialisation of television, there was a fear that the script and the authored text would suffer as a consequence. However, The Avengers, and later The Prisoner, demonstrated how a programme could work aesthetically on celluloid and, with its logic of variation/replication, produce a generic aggregation that prefigured a sceptical and open postmodernism

In some ways, The Avengers and The Prisoner both used an aesthetics that occupied a space beyond ideology, that of pure pleasure. The extreme selfconscious use of style attributed to both these series in the late 1960s, is explained not only through reference to individual aesthetic or cultural influences, but through attention to the transformation of the TV industry into a new transatlantic form of entertainment that depended on celluloid television. Television is a process that brings the social and technological together. The notion of ideology as the chief mediator between the televisual and the non-televisual which implies that television technology is ideologically complicit assumes that there is such a thing as a neutral technology. Although technology is not ideological in itself, it is ideological in its use in specific historical situations, and therefore, an historical examination of a technological development is required. ${ }^{25}$ Television's specificity cannot simply be defined in terms of the 'film look' and the similarity of the television genre to film genre, but must be seen in terms of the ideologies used to create such cult shows as The Avengers and The Prisoner, a combination of imperial decline, notions of Britishness, and conspicuous consumption represented by the worlds of fashion and art.

\section{Birkbeck College, University of London}

\section{Notes}

1. John Hill and Martin McLoone (eds), Big Picture, Small Screen (London: John Libbey Media, 1995), p. 62n. Desilu is a production company formed by Lucille Ball (of I Love Lucy fame) and her husband Desi Arnaz - their most famous and recognisable show was Star Trek.

2. Thomas Edison, in 'The World's Columbian Exposition Illustrated', May 1893, quoted in Gordon Hendricks, The Edison Motion Picture Myth (Berkeley and Los Angeles: University of California Press, 1961), p. 104.

3. Peter Kramer, 'The Lure of the Big Picture: Film, Television and Hollywood' in Hill and McLoone (eds), Big Picture, Small Screen, p. 16.

4. <http://en.wikipedia.org/wiki/File:Telephonoscope.jpg> [accessed 19 May 2010].

5. Roy Armes, On Video (London: Routledge, 1988), p. 34.

6. William Boddy, 'The Shining Centre of the Home: Ontologies of Television in the Golden Age' in Television in Transition, ed. by Phillip Drummond and Richard Patterson (London: BFI, 1986), p. 131

7. Nigel Kneale,' Not Quite So Intimate', Sight and Sound, 28 (1959), 86-8 (p. 87). 
8. Richard Patterson, 'Introduction', in Television: An International History, ed. By Richard Patterson and Anthony Smith, 2nd edn (Oxford and New York: Oxford University Press, 1998), pp. 1-6; p. 3.

9. Philip Mackie, 'Six Hundred Hours a Week', Sight and Sound, 24 (1954), 45-48 (p. 48).

10. Quoted in D. J. Kimbley, 'Survival of celluloid in the age of the microelectronic in television', The Journal of the Royal Television Society (September-October 1981), 21-24 (p. 21).

11. Stuart Hall, 'Television and Culture', Sight and Sound, 45 (1976), 246-252 (p. 249).

12. Pierre Macherey, A Theory of Literary Production, (London: Routledge, 1978), p.49.

13. 'An interview with Pierre Macherey', Red Letters, 5 (1977), 3-9 (p. 7).

14. Alan Hume, 'Filming for Colour Television Series', British Kinematograph Sound and Television, 50 (1968), 3-5 (p. 3, 5).

15. Thomas Schatz, Hollywood genres: formulas, filmmaking, and the studio system (New York: Random House, 1981).

16. Steve Neale, Genre (London: British Film Institute, 1980), p. 48.

17. David Buxton, From The Avengers to Miami Vice (Manchester: Manchester University Press, 1990), p. 98.

18. Harry Craig, as quoted in Buxton, p. 98.

19. John Caughie, Television Drama: Realism, Modernism and British Culture (Oxford: Oxford University Press, 2000), p. 54.

20. Peter Black, 'Undercover and out of mind except for that Mrs Gale', Daily Mail, 13 October 1962, p. 4.

21. As quoted in TV Times, 9-15 February 1964, p. 7.

22. Bruce Merry, Anatomy of the Spy Thriller (Dublin: Gill and Macmillan, 1977), pp. 162-3.

23. 'New on Southern This Week', TV Times, 30 September - 6 October 1967, p. 4.

24. Alain Carraze and Helene Oswald, The Prisoner (London: Virgin, 1990), p. 53.

25. James Spellerberg, Technology and the Film Industry: the adoption of cinemascope (Ann Arbor, MI: University Microfilms International, 1980), n.p.

\section{Works Cited}

Armes, Roy, On Video (London: Routledge, 1988)

Black, Peter, 'Undercover and Out Of Mind Except for That Mrs Gale ', Daily Mail, 13 October 1962, p. 4.

Buxton, David, From The Avengers to Miami Vice (Manchester: Manchester University Press, 1990)

Alain Carraze and Helene Oswald, The Prisoner (London: Virgin, 1990)

Caughie, John, Television Drama: Realism, Modernism and British Culture (Oxford: Oxford University Press, 2000)

Drummond, Phillip, and Richard Patterson Television in Transition (London: BFI, 1986)

Hall, Stuart, 'Television and Culture', Sight and Sound, 45 (1976), 246-252

Nigel Kneale,' Not Quite So Intimate', Sight and Sound, 28 (1959), 86-8

Hendricks, Gordon, The Edison Motion Picture Myth (Berkeley and Los Angeles: University of California Press, 1961)

Hill, John and Martin McLoone (eds), Big Picture, Small Screen (London: John Libbey Media, 1995)

Hume, Alan, 'Filming for Colour Television Series', British Kinematograph Sound and Television, 50 (1968), 3-5 
D. J. Kimbley, 'Survival of celluloid in the age of the microelectronic in television', The Journal of the Royal Television Society (September-October 1981), 21-24 (p. 21)

Mackie, Philip, 'Six Hundred Hours a Week', Sight and Sound, 24 (1954), 45-48

Macherey, Pierre, A Theory of Literary Production (London: Routledge, 1978)

-_ 'An interview with Pierre Macherey', Red Letters, 5 (1977), 3-9

Merry, Bruce, Anatomy of the Spy Thriller (Dublin: Gill and Macmillan, 1977)

Neale, Steve, Genre (London: British Film Institute, 1980)

Patterson, Richard, 'Introduction', in Television: An International History, ed. by Richard Patterson and Anthony Smith, 2nd edn (Oxford and New York: Oxford University Press, 1998)

Schatz, Thomas, Hollywood genres: formulas, filmmaking, and the studio system (New York: Random House, 1981)

Spellerberg, James, Technology and the Film Industry: the adoption of cinemascope (Ann Arbor, MI: University Microfilms International, 1980), n.p. 